\title{
Facile Fabrication of DNA Biosensors Based on Oxidized Carbon Black and Graphite Oxide ${ }^{\dagger}$
}

\author{
Mahsa Moshari, Dipak Koirala and Peter B. Allen * \\ Department of Chemistry, University of Idaho, Moscow, ID 83843, USA; \\ mosh3458@vandals.uidaho.edu (M.M.); koir6878@vandals.uidaho.edu (D.K.) \\ * Correspondence: pballen@uidaho.edu \\ + Presented at the 23rd International Electronic Conference on Synthetic Organic Chemistry, \\ 15 November-15 December 2019; Available online: https://ecsoc-23.sciforum.net/.
}

Published: 14 November 2019

\begin{abstract}
We investigated electrochemical sensors based on graphite oxide $(\mathrm{GrO})$ and oxidized carbon black $(\mathrm{CbO})$. $\mathrm{GrO}$ and $\mathrm{CbO}$ were synthesized by the modified Hummers method. Singlestranded DNA (ssDNA) probes were synthesized with a 5' primary amine for attachment. These ssDNA oligonucleotides were immobilized on $\mathrm{GrO}$ and $\mathrm{CbO}$ using standard 1-ethyl-3-(3-dimethyl aminopropyl) carbodiimide (EDC) coupling. This formed an amide bond between the DNA-amine and carboxyl groups on $\mathrm{GrO}$ and $\mathrm{CbO} . \mathrm{GrO}$ and $\mathrm{CbO}$ were used instead of graphite in a carbon paste material. This significantly enhanced the sensitivity of the biosensor for the reversecomplementary DNA. We detected reverse-complimentary DNA using Electrochemical Impedance Spectroscopy (EIS) and Cyclic Voltammetry (CV) in a ferricyanide solution. The solution was spiked with the ssDNA oligonucleotide with the reverse-complementary sequence of the immobilized probe. The change in current or impedance was measured. We present early work on optimizing the fabrication method for DNA-functionalized carbon electrodes. Working electrodes were fabricated by drop-casting the active material onto a glassy carbon electrode surface.
\end{abstract}

Keywords: biosensors; EDC coupling; carbon black; graphite oxide

\section{Introduction}

Biosensors can detect diverse analytes. We want to detect nucleic acids from pathogens. If our sensor is sensitive, we can detect contamination in food or drugs. Electrochemical biosensors have been demonstrated by many groups for this purpose. Electrochemical biosensors are inexpensive, sensitive, simple, and rapid [1-3]. Label-free, electrochemical DNA detection is especially attractive as it does not require chemically modified probes [4]. However, DNA probes for electrochemical detection must be conjugated to the electrode surface. This can be accomplished by covalent attachment to carbon or by a gold-thiol link. Most electrochemical methods use gold electrodes and thiol attachment chemistry. We demonstrate an alternative with several advantages [5,6]. We show that DNA can be conjugated to specific forms of carbon by well-known 1-ethyl-3-(3-dimethyl aminopropyl) carbodiimide (EDC) coupling. The disadvantages of gold-thiol chemistry include a narrow potential window and high cost. Additionally, the surface of bare gold must be pristine for good functionalization. This can lead to irreproducible results. This can be overcome with careful technique but represents a significant barrier to entry.

Carbon electrodes are an attractive alternative. Carbon has a wide potential window, high electron transfer, electrical conductivity, low background current, and is affordable [7]. Graphite oxide and carbon black oxide are widely used in electrochemical biosensors due to their high conductivity at room temperature, high surface area, thermal stability, and low cost [8-11]. These materials can be drop cast onto an existing conductive surface such as a glassy carbon rod. Glassy 
carbon is used for its corrosion resistance and homogenous surface [12]. Different methods have been studied to anchor DNA strands. Other labs have attached DNA by adsorption, entrapment in a polymer matrix, and electrografting [13-15]. In this study, we show that DNA can be directly conjugated to conductive carbon particles. The particles can be formed into an electrode by dropcasting in Nafion. We demonstrate the effectiveness of this approach by detecting reversecomplementary DNA using cyclic voltammetry $(\mathrm{CV})$ and electrochemical impedance spectroscopy (EIS).

\section{Experimental Process}

\subsection{The Materials and Methods Section}

The DNA oligonucleotides used in this paper were synthesized by Integrated DNA Technologies (IDT, Coralville, IA, USA). The sequences of the oligonucleotides were: Probe single-stranded DNA (ssDNA): /5AmMC6/TTGAGGAGGAGGAGGAGAGGCGGGTTGAGG and complementary doublestranded DNA (dsDNA): 5'-TCTCCTCCTCCTCCTCTTTTCTGAATAAGA-3'. 1-ethyl-3-(3-dimethylaminopropyl) carbodiimide hydrochloride (EDC), was purchased from Sigma Aldrich Co. All other reagents were of analytical reagent grade. All of the solutions were prepared with Millipore deionized water.

\subsection{Synthesis of Graphite Oxide and Carbon Black Oxide}

Graphite oxide $(\mathrm{GrO})$ and oxidized carbon black $(\mathrm{CbO})$ were prepared from graphite powder and carbon black powder, respectively, by following Hammer's method. Firstly, $0.5 \mathrm{~g}$ of $\mathrm{NaNO}_{3}$ and $3 \mathrm{~g}$ of graphite powder were dissolved in $25 \mathrm{~mL}$ concentrated $98-99 \%$ sulfuric acid. Then the mixture was stirred for $3 \mathrm{~h}$ in an ice bath. We slowly added $3 \mathrm{~g}$ of $\mathrm{KMnO}_{4}$, as a potent oxidizing agent, to the mixture at room temperature. The mixture was stirred for $12 \mathrm{~h}$. The oxidation reaction was interrupted by the addition of $20 \mathrm{~mL} 30 \% \mathrm{H}_{2} \mathrm{O}_{2}$ solution. Immediately after the addition of $30 \%$ hydrogen peroxide, the color of the mixture changed to pale yellow. Subsequently, $120 \mathrm{~mL}$ of purified water was added to the solution. The resultant product was repeatedly centrifuged with $\mathrm{H}_{2} \mathrm{O}_{2}$ to adjust the $\mathrm{pH}$ to four. The final product was placed in a $60{ }^{\circ} \mathrm{C}$ oven for $12 \mathrm{~h}$. Synthesis of $\mathrm{CbO}$ proceeded in the same manner $[16,17]$.

\subsection{Covalently Immobilization of DNA}

Single-stranded DNA was covalently attached to the carboxyl group of $\mathrm{CbO}$ and $\mathrm{GrO}$ surfaces through EDC coupling. The glassy carbon electrode (GCE) was polished with $0.3 \mathrm{~mm} \gamma-\mathrm{Al}_{2} \mathrm{O}_{3}$, then sonicated in deionized water for about $30 \mathrm{~s}$ and then rinsed with deionized water. For immobilization of the oligonucleotide, $5 \mathrm{mg}$ oxidized graphite and carbon black were suspended in a $1 \mathrm{M}$ MES ( $\mathrm{pH}$ 4.5) containing 0.1 M EDC. Amine-modified ssDNA was added to the suspension $(1 \mu \mathrm{M}$ final concentration) and vortexed for $2 \mathrm{~h}$ at room temperature. The suspension was then washed with PBS buffer ( $\mathrm{pH}$ 7.4) by centrifugation and resuspension. Finally, $50 \mu \mathrm{L}$ of ethanol, $25 \mu \mathrm{L} 5 \% \mathrm{Nafion}$, and $50 \mu \mathrm{L}$ DI water were added. The mixture was sonicated for $1 \mathrm{~h}$. Then, a droplet of $2.5 \mu \mathrm{L}$ of the Nafioncarbon-DNA suspension was applied to the surface of the GCE. For hybridization, $4 \mu \mathrm{L}$ of the complementary oligonucleotide was mixed in $200 \mu \mathrm{L}$ of $20 \mathrm{mM} \mathrm{NaCl}$ in PBS buffer solution (containing $137 \mathrm{mM}$ sodium chloride, $2.7 \mathrm{mM}$ potassium chloride, and $10 \mathrm{mM}$ Phosphate Buffer $\mathrm{pH}$ 7.4) and applied to the ssDNA modified $\mathrm{GrO} / \mathrm{CbO}$. After $20 \mathrm{~min}$, the surfaces were extensively washed for $20 \mathrm{~min}$. Finally, the electrode was dried at room temperature for at least $3 \mathrm{~h}$. Scheme 1 shows the conjugation of an ssDNA onto the GrO surface and hybridization with a complementary target. 

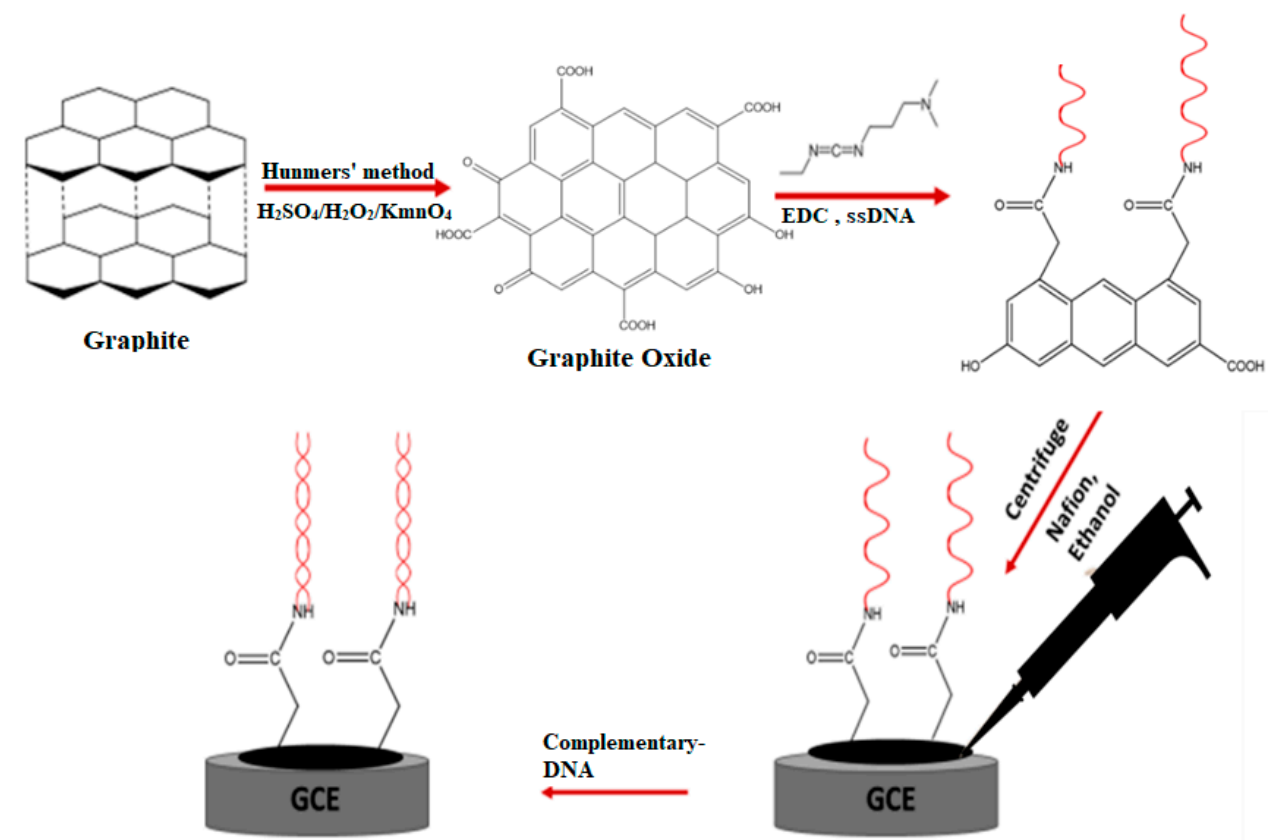

Scheme 1. The immobilization of an ssDNA onto the graphite oxide (GrO) surface and hybridization with a complementary target. EDC: 1-ethyl-3-(3-dimethyl aminopropyl) carbodiimide; glassy carbon electrode.

\subsection{Electrochemical Detection}

A conventional three-electrode system (Pine WaveDriver Galvanostat, Pine Instruments, Durham, NC, USA) was used for electrochemical characterization with modified $\mathrm{GrO} / \mathrm{CbO}$ coated glassy carbon as working electrode, saturated $\mathrm{Ag} / \mathrm{AgCl}(3.5 \mathrm{M} \mathrm{KCl})$ as a reference electrode, and $\mathrm{Pt}$ as a counter electrode in a $0.1 \mathrm{M} \mathrm{KCl}$ solution containing $6 \mathrm{mM}$ of $\mathrm{K}_{3} \mathrm{Fe}(\mathrm{CN})_{6}$. All measurements were performed at room temperature. Cyclic voltammetry and electrochemical impedance spectroscopy of the redox probe were performed to detect reverse-complimentary DNA. Cyclic voltammetry measurements were carried out between $-0.4 \mathrm{~V}$ and $0.6 \mathrm{~V}$. The scan rate of these measurements was $100 \mathrm{mV} \mathrm{s}^{-1}$. EIS was performed to monitor the whole procedure in the modification of the electrodes. Impedance measurements were carried out between $1 \mathrm{MHz}$ and $1 \mathrm{~Hz}$ applying an AC amplitude of $25 \mathrm{mV}$. The electrolyte for the impedance measurement was $1 \mathrm{M} \mathrm{KCl}$, containing $6 \mathrm{mM}$ potassium ferricyanide.

\section{Result and Discussion}

Figure 1 presents the performance of the $\mathrm{CbO}$ and $\mathrm{GrO}$ electrodes conjugated to DNA. Singlestranded DNA (ssDNA) was immobilized on the surface through the formation of covalent amide bonds between the amino groups of the oligonucleotides and carboxyl groups on the $\mathrm{GrO}$ and $\mathrm{CbO}$. In Figure 1B, the anodic and cathodic current at $180 \mathrm{mV}$ was the oxidation and reduction of iron cyanide in solution. The electron transfer (and, therefore, the current) was reduced when the electrode was conjugated to DNA (Figure 1A(II)). The current was further reduced when complementary DNA was added (Figure 1A(III)). Figure 1C shows the performance of the $\mathrm{CbO}$ electrode conjugated to DNA. Conjugation $\mathrm{CbO}$ to DNA also caused a decrease in charge transfer and reduced current. We attributed the reductions in current to the electrostatic repulsion between DNA and ferricyanide. This increased after the addition of complementary DNA. 


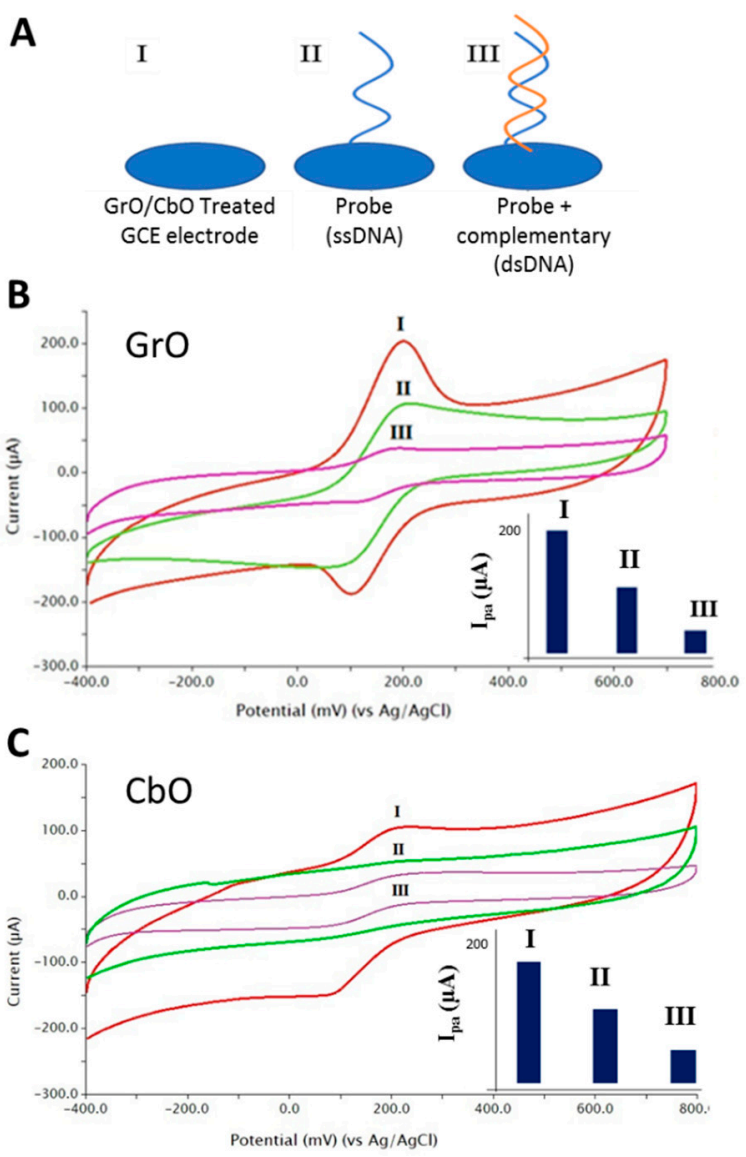

Figure 1. DNA conjugation detected with Cyclic Voltammetry. (A) The schematic shows (I) the noDNA control, (II) single-stranded DNA (ssDNA)-coated electrode, and (III) the double-stranded DNA (dsDNA)-coated electrode. (B) Cyclic voltammograms of the GrO-modified electrodes recorded in 10 $\mathrm{mM}$ potassium ferricyanide $\left[\mathrm{K}_{3} \mathrm{Fe}(\mathrm{CN})_{6}\right]$ in $1 \mathrm{M}$ potassium nitrate at a scan rate of $0.1 \mathrm{Vs}^{-1}$, in the potential range between -0.4 to $+0.7 \mathrm{~V}$ A. for the (I) GrO electrode, (II) ssDNA-GrO electrode, and (III) dsDNA-GrO electrode. (C) Equivalent cyclic voltammograms for (I) CbO electrode, (II) ssDNA-CbO electrode, and (III) dsDNA-CbO electrode. Insets show the baseline-corrected peak anodic current for each sample.

We interpreted the greater reduction in current on $\mathrm{GrO}$ (as compared to $\mathrm{CbO}$ ) to two causes: lower resistance and more efficient functionalization. GrO showed higher efficiency charge transfer from $\mathrm{GrO}$ to ferricyanide. The current for the unmodified $\mathrm{GrO}$ was much higher than the unmodified $\mathrm{CbO}$. High performance of charge transfer on $\mathrm{GrO}$ was due to the regular structure of graphite (which reduces resistance). $\mathrm{GrO}$ also showed better functionalization. $\mathrm{GrO}$ consists of graphene oxide sheets and displays oxygen-containing functional groups on the surface (alcohols, quinones, and carboxylic acids). As a consequence, GrO has a high potential to create a covalent bond between oxygen and amines [18-20].

Nyquist plots of the EIS spectra of $\mathrm{CbO} / \mathrm{GrO}$ electrodes in a $1 \mathrm{M} \mathrm{KCl}$ aqueous solution containing $6 \mathrm{mM}\left[\mathrm{K}_{3} \mathrm{Fe}(\mathrm{CN})_{6}\right]$ are shown in Figure 2. The bare $\mathrm{GrO} / \mathrm{CbO}$ electrodes had a small AC impedance, indicating that the electron transfer between the electrode and electrolyte was fast (Figure 1B,C). The $\mathrm{AC}$ impedance increased after the $\mathrm{GrO} / \mathrm{CbO}$ were conjugated to the DNA. This suggested more resistance to electron transfer between the electrode and the ferricyanide. The resistance was further increased when complementary DNA is added. EIS corroborated the CV results and indicated that the $\mathrm{GrO}$ had a lower resistance to electron transfer compared to the $\mathrm{CbO}$ electrode. 


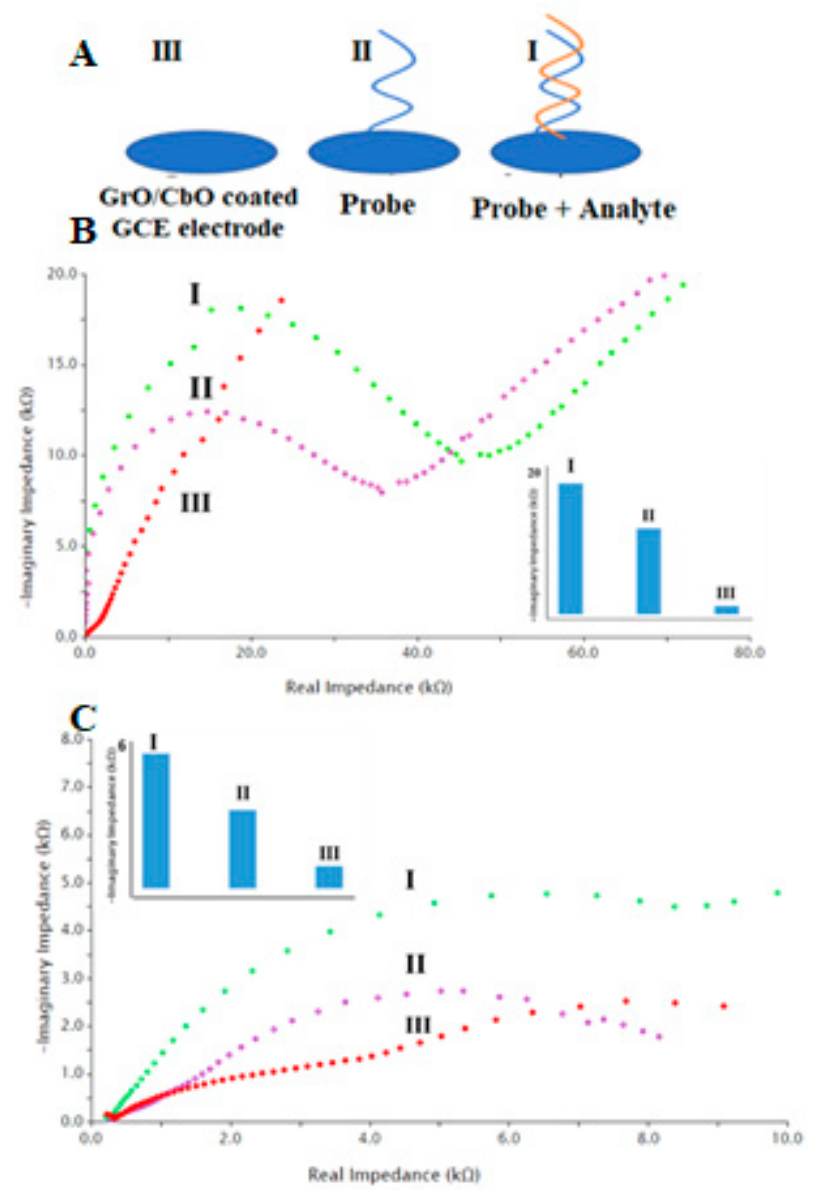

Figure 2. DNA conjugation detected with Electrochemical Impedance Spectroscopy (EIS). (A) A schematic shows (I) the no-DNA control, (II) ssDNA-coated electrode, and (III) dsDNA-coated electrode. (B) Nyquist plots of the EIS spectra recorded in $10 \mathrm{mM}$ potassium ferricyanide $\left[\mathrm{K} 3 \mathrm{Fe}(\mathrm{CN})_{6}\right]$ in $1 \mathrm{M}$ potassium nitrate at a frequency between $1 \mathrm{MHz}$ and $1 \mathrm{~Hz}$ and an $\mathrm{AC}$ amplitude is $25 \mathrm{Mv}$ for (I) GrO electrode, (II) ssDNA-GrO electrode, and (III) dsDNA-GrO electrode. (C) Equivalent Nyquist plots for the EIS spectrum of (I) CbO electrode, (II) ssDNA-CbO electrode, and (III) dsDNA-CbO electrode.

\section{Conclusions}

This study has introduced a method for conjugating amine-modified DNA to carbon black oxide and graphene oxide. We showed that graphene oxide and carbon black oxide bind DNA, and this prevents charge transfer to ferricyanide. This phenomenon allows for detecting reversecomplementary DNA. Reduced peak current was attributed to the complementary DNA. This is a label-free biosensor; it requires no indicators or labels on the DNA. We show that graphite oxide is superior in performance to carbon black oxide. We attribute the higher performance to the ordered structure and lower resistance in graphite oxide compared to the more disordered, paracrystalline structure of carbon black [21]. This is a simple and rapid conjugation method for generating DNA sensors.

\section{References}

1. Prajapati, D.G.; Kandasubramanian, B. Progress in the Development of Intrinsically Conducting Polymer Composites as Biosensors. Macromol. Chem. Phys. 2019, 220, doi:10.1002/macp.201800561.

2. Yola, M.L.; Eren, T.; Atar, N. A novel and sensitive electrochemical DNA biosensor based on Fe@ Au nanoparticles decorated graphene oxide. Electrochim. Acta 2014, 125, 38-47.

3. Rashid, J.I.A.; Yusof, N.A. The strategies of DNA immobilization and hybridization detection mechanism in the construction of electrochemical DNA sensor: A review. Sens. Bio-Sens. Res. 2017, 16, 19-31. 
4. Aghaei, F.; Seifati, S.M.; Nasirizadeh, N. Development of a DNA biosensor for the detection of phenylketonuria based on a screen-printed gold electrode and hematoxylin. Anal. Methods 2017, 9, 966-973.

5. Beebe, T.P.; Rabke-Clemmer, C.E. Thiol Labeling of DNA for Attachment to Gold Surfaces. U.S. Patent 5472881A, 5 December 1995.

6. Silva, M.M.; Cavalcanti, I.T.; Barroso, M.F.; Sales, M.G.F.; Dutra, R.F. Gold electrode modified by selfassembled monolayers of thiols to determine DNA sequences hybridization. J. Chem. Sci. 2010, 122, 911917.

7. Wang, Z.; Dai, Z. Carbon nanomaterial-based electrochemical biosensors: An overview. Nanoscale 2015, 7, 6420-6431.

8. Silva, T.A.; Moraes, F.C.; Janegitz, B.C.; Fatibello-Filho, O. Electrochemical biosensors based on nanostructured carbon black: A review. J. Nanomater. 2017, doi:10.1155/2017/4571614.

9. Karim, M.R.; Hatakeyama, K.; Matsui, T.; Takehira, H.; Taniguchi, T.; Koinuma, M.; Matsumoto, Y.; Akutagawa, T.; Nakamura, T.; Noro, S.-I. Graphene oxide nanosheet with high proton conductivity. J. Am. Chem. Soc. 2013, 135, 8097-8100.

10. Qiu, J.-D.; Huang, J.; Liang, R.-P. Nanocomposite film based on graphene oxide for high performance flexible glucose biosensor. Sens. Actuators B Chem. 2011, 160, 287-294.

11. Rahimi, R.; Moshari, M.; Rabbani, M.; Azad, A. Photooxidation of benzyl alcohols and photodegradation of cationic dyes by $\mathrm{Fe}_{3} \mathrm{O}_{4} @$ sulfur/reduced graphene oxide as catalyst. RSC Adv. 2016, 6, 41156-41164.

12. Wang, J.; Kirgöz, Ü.A.; Mo, J.-W.; Lu, J.; Kawde, A.N.; Muck, A. Glassy carbon paste electrodes. Electrochem. Commun. 2001, 3, 203-208.

13. Okahata, Y.; Kobayashi, T.; Tanaka, K.; Shimomura, M. Anisotropic electric conductivity in an aligned DNA cast film. J. Am. Chem. Soc. 1998, 120, 6165-6166.

14. Semenza, G.L.; Prabhakar, N.R. The role of hypoxia-inducible factors in oxygen sensing by the carotid body. In Arterial Chemoreception; Springer: Berlin/Heidelberg, Germany, 2012; pp. 1-5.

15. LaBuda, C.J.; Fuchs, P.N. Aspirin attenuates the anxiolytic actions of ethanol. Alcohol 2000, 21, $287-290$.

16. Moshari, M.; Rabbani, M.; Rahimi, R. Synthesis of TCPP-Fe3 $\mathrm{O}_{4} @ \mathrm{~S} / \mathrm{RGO}$ and its application for purification of water. Res. Chem. Intermed. 2016, 42, 5441-5455.

17. Rahimi, R.; Moshari, M.; Rabbani, M. Photocatalytic Degredration of Methylene Blue and Crystal Violet by Sulfur/Reduced Graphene Oxide Composite. In Proceedings of the 18th International Electronic Conference on Synthetic Organic Chemistry, 1-30 November 2014.

18. Gudarzi, M.M.; Sharif, F. Enhancement of dispersion and bonding of graphene-polymer through wet transfer of functionalized graphene oxide. Express Polym. Lett. 2012, 6, 1017-1031.

19. Sun, W.; Zhang, Y.; Hu, A.; Lu, Y.; Shi, F.; Lei, B.; Sun, Z. Electrochemical DNA biosensor based on partially reduced graphene oxide modified carbon ionic liquid electrode for the detection of transgenic soybean A2704-12 gene sequence. Electroanalysis 2013, 25, 1417-1424.

20. Sun, W.; Zhang, Y.; Ju, X.; Li, G.; Gao, H.; Sun, Z. Electrochemical deoxyribonucleic acid biosensor based on carboxyl functionalized graphene oxide and poly-l-lysine modified electrode for the detection of th gene sequence related to vibrio parahaemolyticus. Anal. Chim. Acta 2012, 752, 39-44.

21. Hess, W.; Ban, L.; McDonald, G. Carbon black morphology: I. Particle microstructure. II. Automated EM analysis of aggregate size and shape. Rubber Chem. Technol. 1969, 42, 1209-1234.

(C) 2019 by the authors. Licensee MDPI, Basel, Switzerland. This article is an open access article distributed under the terms and conditions of the Creative Commons Attribution (CC BY) license (http://creativecommons.org/licenses/by/4.0/). 